\title{
Growth patterns and nutrition in Nepali children
}

\author{
S. MARGARET FARQUHARSON
}

\begin{abstract}
Farquharson, S. M. (1976). Archives of Disease in Childhood, 51, 3. Growth patterns and nutrition in Nepali children. A growth survey of four groups of Nepali children from birth to 12 years was undertaken and the growth patterns related to diet. The patterns are those of children suffering from malnutrition in the second and third year and not those of a genetically small race. Diet histories showed inadequacies of diet, mostly preventable, occurring during the same period. Privileged children within the groups showed a different pattern and a significantly better growth.
\end{abstract}

For a long time the Nepalis have been regarded as a race of small stature, and when it was observed that the weight and height measurements of their infants and children were almost universally below Western standards it was felt initially that a different set of standards would have to be devised for what appeared to be a genetically small race. This view was also supported by the fact that though many children looked obviously malnourished, many others, while well below the 10th centile of Western standards, were well proportioned, apparently healthy, and had no obvious deficiency disease.

However, recent studies in other areas (Habicht et al., 1974) have shown that the early growth of well-nourished children from different ethnic backgrounds is similar, and that at least until 7 years of age standards of normal growth derived from children in developed countries are applicable also to the underdeveloped countries. Waterlow (1974) stresses that stunting without wasting is commonly seen in the older children in a malnourished community, and that while wasting is an indication of present malnutrition, stunting is the stigma of previous malnutrition. It therefore seemed possible that the Nepali children were stunted rather than genetically small, especially as it was noted that the children of the privileged were obviously taller and heavier. It was decided therefore to compare the growth patterns of the different ethnic groups in Nepal and also to compare the growth of a group of privileged children with that of a group of nonprivileged of the same ethnic group, and in each case to relate the growth patterns to diet.

Received 23 April 1975.

\section{Material and methods}

Ethnic groups. Although Nepal is a small country, there is a great variety of ethnic groups, which in addition to being racially distinct, differ in religion, customs, and language. For this study four major ethnic groups were examined.

Newars. These are the original inhabitants of the fertile valley surrounding Kathmandu. Many are farmers but the majority are traders, shopkeepers, and craftsmen living an urban existence in crowded towns and villages. Their language is Newari and they are of mixed Hindu and Buddhist religion.

Brahmins and Chettris. The Brahmins, a high caste Hindu people from North India, invaded the Western hill area of Nepal in the 12th century driving the TibetoBurmese inhabitants of this region northwards. Also living in the area were the Khas, a people of Aryan stock, racially akin to the Brahmins but Buddhist. Khas who were converted to Hinduism and progeny of mixed Kha/Brahmin parentage became known as Chettris, and they adopted most of the customs of the Brahmins.

The Chettri House of Gurkha conquered the Newars of the Kathmandu valley in the 18th Century and the unification of the country followed soon after with the Chettris and Brahmins becoming the ruling group, and their language, Nepali, the official language of the country. Though there are still many in positions of importance in the capital, there are others living in valley villages similar to the Newars, and many more who are farmers in the lower foothills in West Nepal. The ethnically similar but culturally different low caste occupational castes of Aryan stock were excluded from the study.

Middle hill people (Tamangs). Throughout the hills of Nepal live tribes of Tibeto-Burmese origin. The 
Tamangs were chosen as they are the most accessible from Kathmandu, living in scattered farming villages in the hills to the North of the valley at altitudes between 5000 and 7000 feet. Most Tamangs are poor, few have received an education, and poverty is increased, in some areas, where they are tenant farmers, parting with as much as half of the harvest to landlords. Their language is Tamang and they are Buddhist.

Tibetan type people. There are two major subgroups of these people living in Nepal. (1) All along the Northern border of the country live people who are ethnically and culturally Tibetan, though by definition Nepali. The nearest such group to Kathmandu are the Helambu Sherpas who live in the hills to the north at altitudes between 7000 and 10000 feet. The people are farmers and traders, the villages relatively wealthy, and part of the income is from the Tamang tenant farmers lower in the valley.

(2) In the 1950s many refugees from central Tibet entered Nepal and came to the centres of refugee aid in the Kathmandu valley. Some have remained in the camps but the majority have left, and as they own no land, have become traders and shopkeepers in the capital. The Tibetan type people are Buddhist and their language is either Tibetan or the closely related Sherpa dialect.

The fifth main group, the people of Aryan stock who inhabit the plains in the south of the country were not studied.

Source of children. The infants and children studied were collected by house-to-house visiting and at clinics. In most villages of the Kathmandu valley either the Government or the United Mission runs 'Under 5's Clinics' for basically healthy children. Recording was carried out at 10 such clinics and also children presenting at Shanta Bhawan hospital with acute, nonwasting illnesses were included. All birthweights are from the maternity unit of this hospital. House-to-house visiting was undertaken in several villages of the valley in addition to the hill regions.

The Brahmins and Chettris were from the farming villages in the Gurkha hill region in addition to the Kathmandu valley. The Tamangs were from the hills at the edge of the valley, the Trisuli area, and from the Helambu valley. The Tibetan type group were from the nursery and school of the Jwalikhel refugee camp, independent refugees in the valley, and from the Sherpas of the Helambu valley.

The privileged group was drawn from those attending private patient clinics, health workers' children, and pupils in private schools. Only children of Newari, Chettri, and Brahmin stock were included in this group, which was used for comparison with the nonprivileged of the same stock.

Measurements. The study consisted of two main parts: (1) infants under 2 years, and (2) children from 2 to 12 years. In the infant group in addition to recording the age in months, ethnic group, and sex, the weight, height, arm and skull circumferences were measured, and the diet assessed by questioning the mother. In the older group the ages were recorded in years, and height was the only measurement taken in all the children. Jelliffe and Jelliffe (1969) suggested that the status of child nutrition in a community could be assessed by measurement of arm circumference at the midpoint of the upper arm, any child over 1 year and under 5 years with an arm circumference less than $14 \mathrm{~cm}$ being regarded as malnourished. Arm circumference measurements were therefore continued up to 5 years.

A series of skull circumference measurements were made in the 10- to 12-year-old group.

In measuring weight, a single spring balance, reading to a maximum of $20 \mathrm{~kg}$, was used in conjunction with a cloth sack. The measurements were taken to the nearest $0 \cdot 1 \mathrm{~kg}$. Outer clothes and shoes were removed but it would have been unacceptable to the mothers to have undressed the infants completely. All other measurements were taken with a tape measure, height being recorded to the nearest $\mathrm{cm}$ and skull and arm circumference to the nearest half $\mathrm{cm}$. Height was taken as supine length until around 7 months, the infant lying on the tape measure on a flat surface with the hip and knee held extended. After this age all measurements were taken standing with the younger ones supported upright. Where possible, and especially in the older children, the tape measure was held against a vertical pillar or wall and the child stood against it. 20 children in each of the three age groups (1) under 7 months (supine), (2) under 2 years (standing), and (3) over 2 years (standing) were measured twice within 24 hours. The standard deviations of the differences between the two measurements were $0.9,0.9$, and $0.7 \mathrm{~cm}$. Arm circumference was measured as described earlier and the skull measurements were taken as the maximum occipitofrontal circumference. As some of the villages studied are 4 days walk from Kathmandu and all equipment had to be carried, it was not possible to use more accurate but heavier means of measurement. All measurements were taken by a single observer in an attempt to reduce errors.

Ages. Age reckoning in Nepal is both complicated and varied. The age in months, as calculated by the mother, is 1 or 2 months older than the infant's actual age, and age in years is either correct or 1 year older. This error was eliminated as far as possible by carrying a Nepali calendar, asking in which month the infant was born and calculating from there. Infants' ages were recorded as completed months, and on the charts are plotted as if all had completed that number of months 2 weeks previously. In the older children once the number of completed years had been established they were charted as if all had completed that number of years 6 months previously.

Diet histories. Language was a considerable problem as only a very few mothers could speak English, and many could speak little or no Nepali, their language being Newari, Tamang, or Tibetan. Over half the mothers were questioned directly in Nepali, or occasion- 
Growth patterns and nutrition in Nepali children

TABLE I

Age and ethnic group distribution of infants studied

\begin{tabular}{|c|c|c|c|c|c|}
\hline & Newars & $\begin{array}{c}\text { Nonprivileged } \\
\text { Chettris } \\
\text { and } \\
\text { Brahmins }\end{array}$ & Tamangs & $\begin{array}{c}\text { Tibetan } \\
\text { type }\end{array}$ & $\begin{array}{c}\text { Privileged } \\
\text { Chettris } \\
\text { and } \\
\text { Brahmins }\end{array}$ \\
\hline $\begin{array}{l}\text { Birth } \\
<6 \mathrm{~m} \\
6 \mathrm{~m}-1 \text { yr } \\
1-2 \mathrm{yr}\end{array}$ & $\begin{array}{r}6 \\
49 \\
40 \\
67\end{array}$ & $\begin{array}{l}11 \\
24 \\
39 \\
46\end{array}$ & $\begin{array}{r}0 \\
22 \\
11 \\
28\end{array}$ & $\begin{array}{r}6 \\
19 \\
22 \\
29\end{array}$ & $\begin{array}{r}5 \\
15 \\
24 \\
16\end{array}$ \\
\hline Total & 162 & 120 & 61 & 76 & 60 \\
\hline
\end{tabular}

ally in English, but for the non-Nepali speakers an interpreter was necessary, sometimes translating directly into English but often only translating into Nepali. All diet histories were taken by a single observer either directly or through interpreters who were often other mothers from the same village.

Distribution of children. A total of 479 infants under the age of 2 years was studied and age and ethnic group distribution is shown in Table I. The study included three sets of twins: one Newar, one Tamang, and one Tibetan. 9 children under 2 years had a younger sib but all those with a younger sib were over 17 months. Questions regarding whether the mother was pregnant proved worthless as pregnancy was firmly denied until near term.

A total of 1656 children aged 2 years or more were studied including 203 Newars, 165 Chettris and Brahmins of the nonprivileged group and 964 of the privileged, 135 Tamang, and 192 of the Tibetan type.

All data were cross-sectional.

\section{Measurements}

Weight, length, and skull circumference in infants under 2 years. Initially the results of the nonprivileged Newars were considered separately from those of the nonprivileged Chettris and Brahmins. However, they did not differ significantly and have been combined to form a single Newar/Chettri/Brahmin group (nonprivileged NCBs) which can be compared with the privileged $N C B s$

Each child's standard of nutrition on weight criteria was gauged and the distribution of the standards in three age categories is shown (Table II) for the four groups:

TABLE II

Distribution of standards of nutrition in three age categories

\begin{tabular}{|c|c|c|c|c|c|c|}
\hline & $50+$ & $50-$ & B & $1^{\circ}$ & $2^{\circ}$ & $3^{\circ}$ \\
\hline $\begin{array}{l}\text { (a) Nonprivileged NCBs } \\
0-5 \mathrm{~m} \\
5-11 \mathrm{~m} \\
12 \mathrm{~m}+\end{array}$ & $\begin{array}{l}8 \\
1 \\
0\end{array}$ & $\begin{array}{r}25 \\
13 \\
6\end{array}$ & $\begin{array}{l}11 \\
13 \\
18\end{array}$ & $\begin{array}{l}14 \\
31 \\
40\end{array}$ & $\begin{array}{r}8 \\
13 \\
37\end{array}$ & $\begin{array}{r}7 \\
8 \\
12\end{array}$ \\
\hline $\begin{array}{l}\text { (b) Privileged NCBs } \\
0-5 \mathrm{~m} \\
5-11 \mathrm{~m} \\
12 \mathrm{~m}+\end{array}$ & $\begin{array}{l}3 \\
3 \\
0\end{array}$ & $\begin{array}{r}3 \\
13 \\
9\end{array}$ & $\begin{array}{l}2 \\
5 \\
2\end{array}$ & $\begin{array}{l}6 \\
3 \\
5\end{array}$ & $\begin{array}{l}1 \\
0 \\
0\end{array}$ & $\begin{array}{l}0 \\
0 \\
0\end{array}$ \\
\hline $\begin{array}{l}\text { (c) Tamangs } \\
0-5 \mathrm{~m} \\
5-11 \mathrm{~m} \\
12 \mathrm{~m}+\end{array}$ & $\begin{array}{l}6 \\
0 \\
0\end{array}$ & $\begin{array}{l}7 \\
2 \\
4\end{array}$ & $\begin{array}{l}6 \\
3 \\
3\end{array}$ & $\begin{array}{r}3 \\
5 \\
13\end{array}$ & $\begin{array}{l}0 \\
1 \\
5\end{array}$ & $\begin{array}{l}0 \\
0 \\
3\end{array}$ \\
\hline $\begin{array}{l}\text { (d) Tibetan type } \\
0-5 \mathrm{~m} \\
5-11 \mathrm{~m} \\
12 \mathrm{~m}+\end{array}$ & $\begin{array}{r}10 \\
7 \\
3\end{array}$ & $\begin{array}{l}6 \\
9 \\
5\end{array}$ & $\begin{array}{l}0 \\
2 \\
8\end{array}$ & $\begin{array}{r}3 \\
3 \\
11\end{array}$ & $\begin{array}{l}0 \\
1 \\
1\end{array}$ & $\begin{array}{l}0 \\
0 \\
1\end{array}$ \\
\hline
\end{tabular}

$50+$, Weight $>50$ th centile for age and sex on the Gairdner and Pearson standard.

50 -, Weight $<50$ th centile but $>10$ th centile for age and sex.

B. Borderline malnourished-a weight $<10$ th centile but $>80 \%$ of the weight of the 50 th centile.

$1^{\circ}$, 1st degree malnourished-weight between 80 and $70 \%$ of the weight of the 50 th centile.

$2 \circ$, 2nd degree malnourished-weight between 70 and $60 \%$ of the weight of the 50th centile.

$3^{\circ}$, 3rd degree malnourished-weight $<60 \%$ of the weight of the 50 th centile.

Note: Any child whose weight fell on the dividing line between groups was included in the higher group. The concept of Borderline, 1st, 2nd, and 3rd degree malnourished is a modification of the classification of Gomez et al. (1956). 


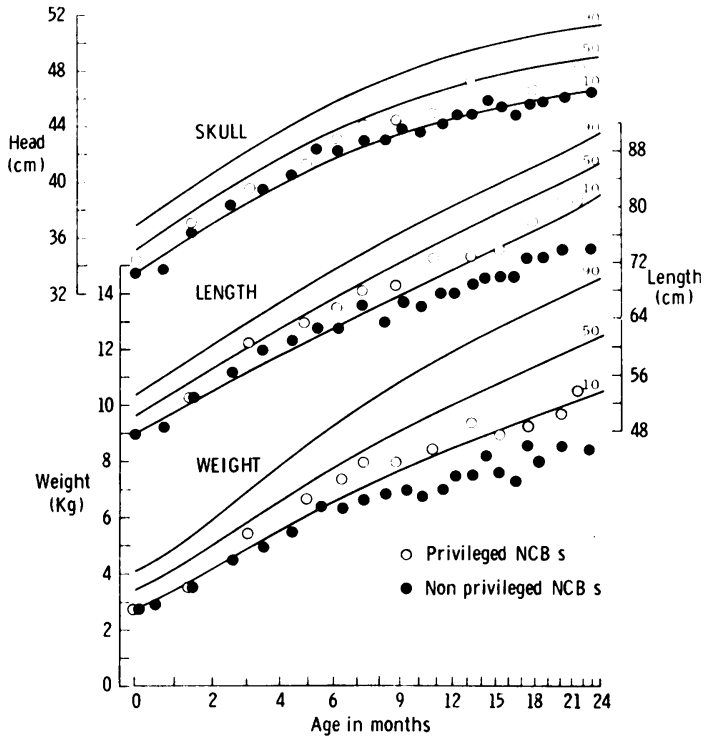

Fig. 1.-Mean measurements of weight, length, and skull circumference of privileged and nonprivileged Newar/ Chettri/Brahmin (NCB) infants under 2 years. The chart is a modified Gairdner and Pearson (1971) chart. The 90th centile is their 90th centile for males, the 10th centile is their 10th centile for females, and the 50th centile is drawn midway between the 50th for males and females.

nonprivileged NCBs, privileged NCBs, Tamangs, and Tibetans. For each month (combined adjacent months when numbers were small) the mean weight, length, and skull circumference for each group were calculated and the means plotted on modified Gairdner and Pearson (1971) charts (Figs. 1 and 2).

From Fig. 1 it can be seen that the mean measurements of the nonprivileged NCB infants lie parallel to, if slightly below, the Gairdner standard until around 7 months, but thereafter fall progressively below the standard. Table IIa also shows that there are proportionally more older malnourished infants. In contrast, the mean measurements of the privileged NCBs as shown in Fig. 1 lie essentially parallel to the Gairdner standard; and Table IIb does not show an increasing number of malnourished with increasing age.

The Tamang growth pattern, as shown in Table IIc and Fig. 2, is similar to that of the nonprivileged NCBs and the means again fall progressively below the standard after 7 months. There are, however, no means below the 10th centile in the first 6 months.

From the Tibetan type data in Table IId, it can be seen that there is a higher percentage of infants in the $50+$ category than in any other ethnic group and it is the only group to have infants of over 1 year in this category. In this group the fall of the means away from the standard occurs later, at around 11 months. A smooth growth curve had not been obtained in the Tibetan type infants.

One problem in interpreting these cross-sectional results in terms of the longitudinal growth pattern of a particular infant is the high mortality. No accurate assessment of this has been made in Nepal but it has been estimated that between 30 and $50 \%$ of the children born are dead before the age of 5 years. Questions regarding death of sibs were not included in the study, but the impression given was that the lower figure was truer in the villages studied.

Arm circumference from birth to 5 years. For each month up to 2 years (combined adjacent months when numbers were small) and for each year up to 5 years the mean arm circumference for each group was calculated and plotted (Figs. 3 and 4). From Fig. 3 it can be seen that the pattern of the privileged NCBs runs almost parallel to, but is always fatter than, the nonprivileged NCBs. The birth difference of $0.4 \mathrm{~cm}$ remains constant until 6 months when it increases over the next 2 months to $1-1.5 \mathrm{~cm}$. This difference is then maintained throughout the preschool years. The only point where the curves do not run parallel is between 6 and 9 months where increase in subcutaneous fat is maintained by the privileged group only.

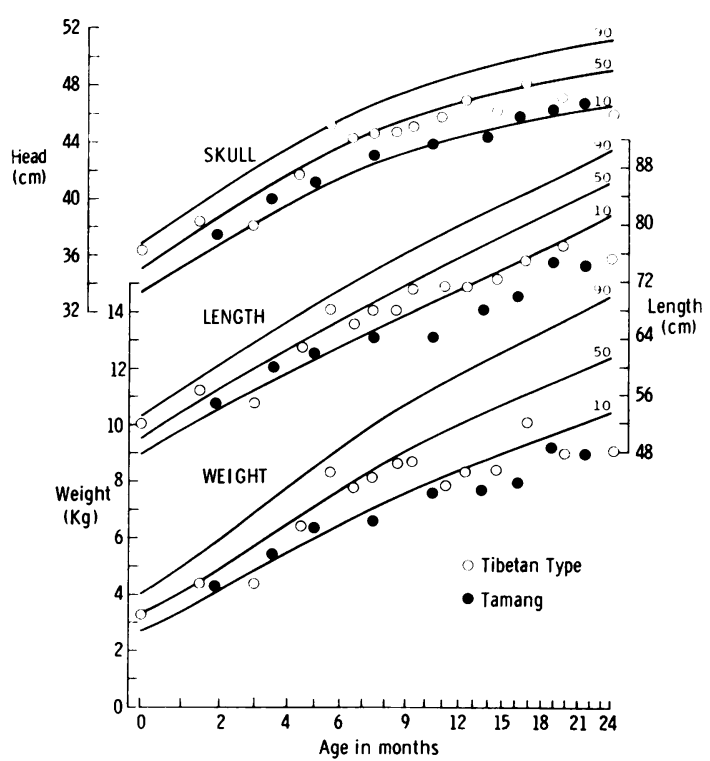

FIG. 2.-Mean measurements of weight, length, and skull circumference of Tamang and Tibetan type infants under 2 years. The chart is a modified Gairdner and Pearson (1971) chart. The 90th centile is their 90th centile for males, the 10th centile is their 10th centile for females, and the 50th centile is drawn midway between the 50th for males and females. 


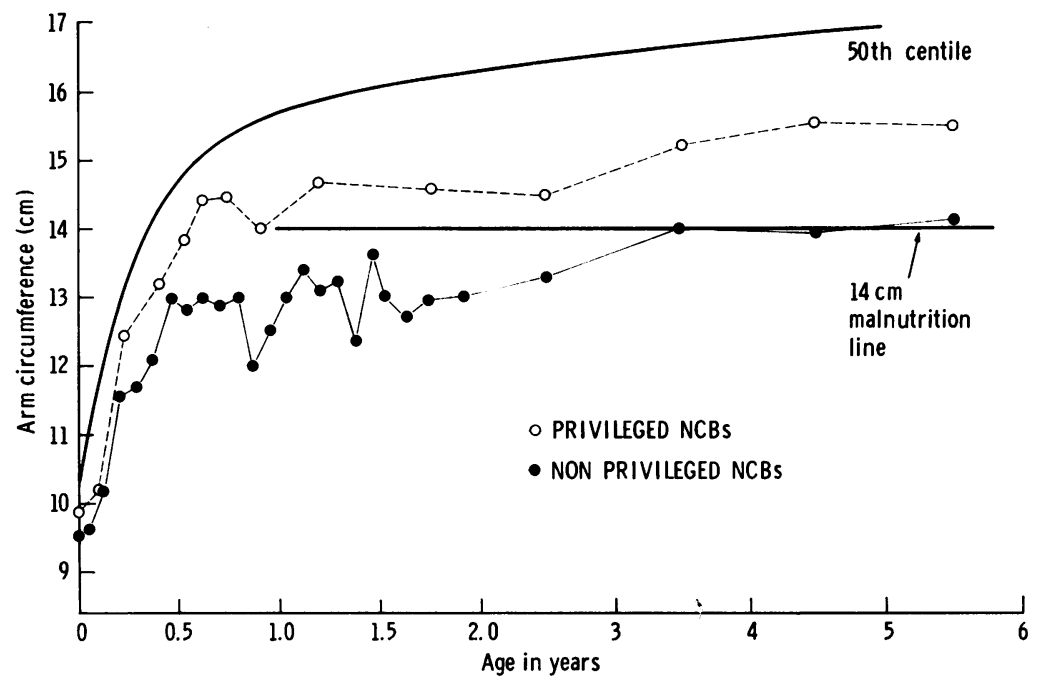

FIG. 3.-Mean measurements of arm circumference from birth to 5 years of privileged and nonprivileged NCBs.

In Fig. 4 the Tamangs can be seen to be following the same general pattern as the nonprivileged NCBs except that from 3 to 6 months the arm circumference is greater. This advantage is maintained throughout the second year but is lost thereafter.

The Tibetan type arm circumference (Fig. 4) is 10.1 $\mathrm{cm}$ at birth $(0.2 \mathrm{~cm}$ fatter than the privileged NCB). Thereafter the pattern is very similar to the privileged NCB with steady increase in the means until around 9 months and thereafter no increase until the third year. The only difference is that in the second year the arm circumference of the Tibetan type decreases whereas that of the privileged NCB merely fails to increase.

In each ethnic group the number of infants classified as malnourished on arm circumference criteria was found to be very similar to the total number in the 1st, 2nd, and 3rd degree malnutrition groups by weight (Table II), e.g. in the nonprivileged NCB group '87 were

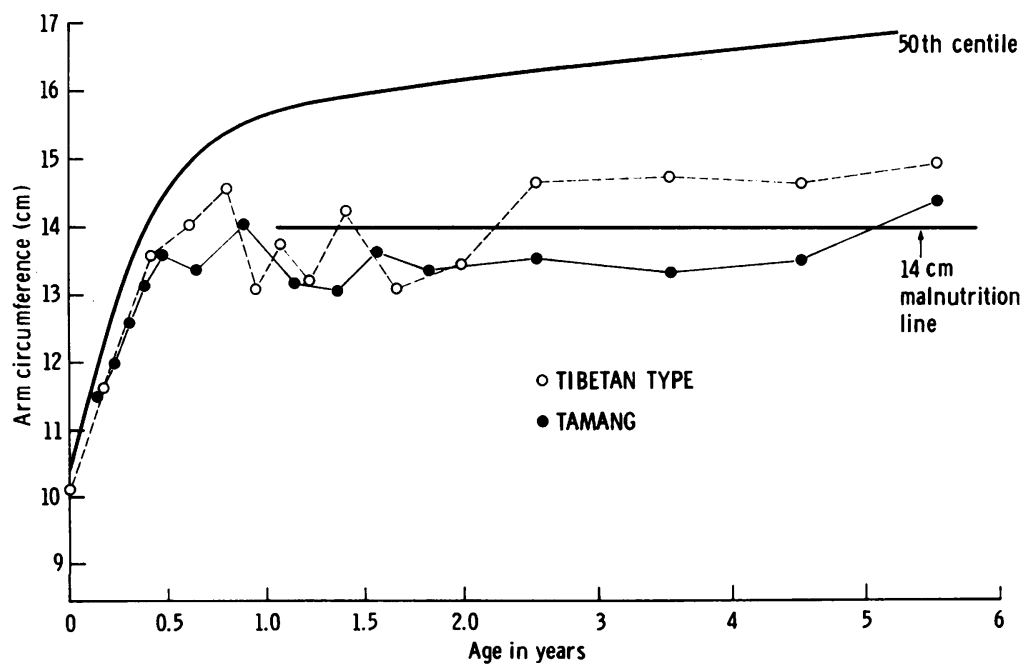

Fig. 4.-Mean measurements of arm circumference from birth to 5 years of Tamang and Tibetan types. 
TABLE III

Height and arm circumference measurements in hill and valley children of the Chettri/Brahmin group

\begin{tabular}{|c|c|c|c|c|c|}
\hline & \multicolumn{2}{|c|}{ Valley $(n=14)$} & \multicolumn{2}{|c|}{ Hill $(n=19)$} & \multirow{2}{*}{$\begin{array}{c}P \\
\text { (Student's } \\
\text { ' } t \text { ' test) }\end{array}$} \\
\hline & Mean & SD & Mean & SD & \\
\hline $\begin{array}{l}\text { Height }(\mathrm{cm}) \\
\text { Arm circumference }(\mathrm{cm})\end{array}$ & $\begin{array}{l}76 \cdot 5 \\
12 \cdot 9\end{array}$ & $\begin{array}{l} \pm 5 \cdot 0 \\
\pm 0.9\end{array}$ & $\begin{array}{l}80 \cdot 5 \\
14 \cdot 0\end{array}$ & $\begin{array}{l} \pm 4 \cdot 0 \\
\pm 1 \cdot 1\end{array}$ & $\begin{array}{l}<\mathbf{0 . 0 2} \\
<\mathbf{0} \cdot \mathbf{0 0 5}\end{array}$ \\
\hline
\end{tabular}

malnourished by weight and 89 were malnourished by arm circumference. It was found that 96 of the 113 infants were in the same category by both methods.

Heights from 2 to 12 years. After combining the 203 nonprivileged Newar children with the 165 nonprivileged Chettri and Brahmin children the mean heights of this combined group were calculated for each year of age. The means are plotted on a Tanner, Whitehouse, and Takaishi (1966) scale in Fig. 5, on which are also plotted the heights of the nonprivileged NCBs under 2 years. It can be seen that the mean height falls progressively below the 10th centile from 6 months until 3 years, after which they lie almost parallel to, but below the 10th centile: at 3 years being $8 \mathrm{~cm}$ below it and at 12 years $12 \mathrm{~cm}$ below.

At each age the mean heights of the Newars and of the Chettri/Brahmin groups were initially calculated separately and compared. At all ages except 2 and 3 years the difference between the means was insignificant and amalgamation of the two groups appeared to be justified. At 2 years the Chettri/Brahmin group was taller by $2.4 \mathrm{~cm}$, and at 3 years by $3.5 \mathrm{~cm}$. The difference at 3 years was of probable significance $(P<0.025$, Student's 't' test).

Within the Chettri/Brahmin group there are two subgroups: those living in the Kathmandu valley, and those on the Gurkha hill farms. At 2 years the hill children were taller by $5 \mathrm{~cm}$ and they were also better nourished by arm circumference criteria (Table III). Between 18 months and 2 years the hill infants were heavier and taller but not significantly so, whereas arm circumference was again significantly greater in the hill infants. The advantage had been lost by 3 years.

The privileged NCBs were also studied initially in their separate groups and combined when no significant difference was found among them. They were also subdivided initially into males and females but, as no difference was found in the means before 9 years the groups at the younger ages were combined. The means of their heights at each age are shown in Fig. 5, as are the heights of priviledged NCBs under 2 years. It can be seen that the mean heights lie around the 25th centile and that after 9 years the girls become increasingly taller than the boys with a difference of $10 \mathrm{~cm}$ by 12 years. This is possibly only a reflection of earlier puberty in the girls but is greater than would have been expected.

Between 5 and 12 years the mean heights of the Tamang and of the Tibetan type groups do not differ from those of the nonprivileged NCBs, but before 5

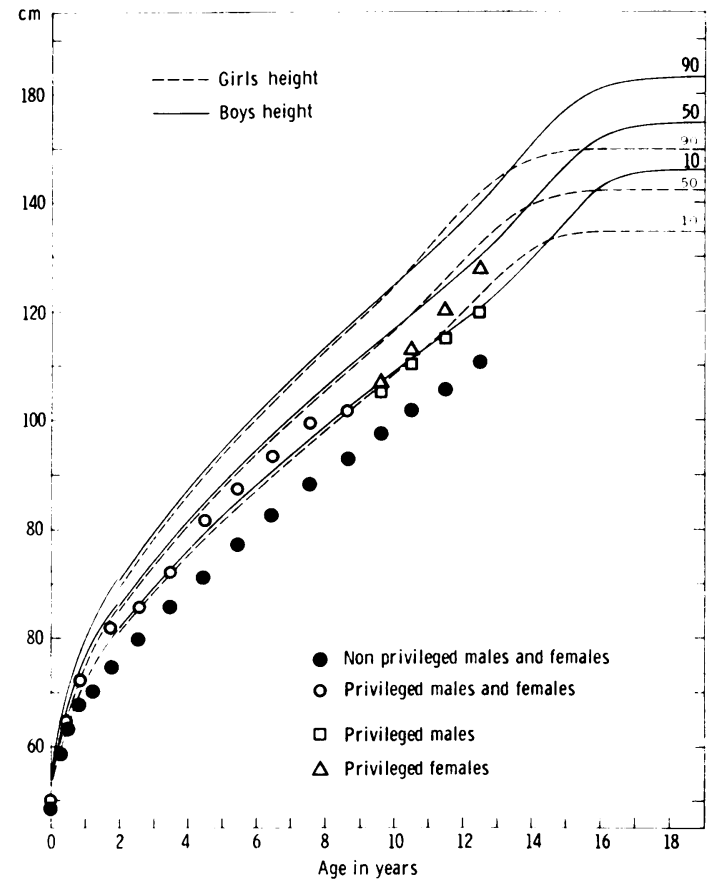

FIG. 5.-Mean measurements of height of privileged and nonprivileged $\mathrm{NCBs}$.

years the Tibetan type children were on average $3 \mathrm{~cm}$ taller and the Tamangs $2 \mathrm{~cm}$ smaller. The gradation in height-privileged, Tibetan, nonprivileged, Tamang -between 2 and 5 years is in the same order as the gradation in arm circumference.

Skull circumference between 10 and 12 years. From Fig. 1 it can be seen that the mean skull circumference falls through the centiles during the second year in the nonprivileged NCB group of infants. By 18 months to 2 years the difference is around $1 \mathrm{~cm}$, with the privileged group on the 25th centile and the nonprivileged just below the 10th centile.

In the 10-, 11-, and 12-year-old children skull circumference was measured in three main groups, privileged NCB males, privileged NCB females, and a mixed group of nonprivileged NCB males and females. 
The mean skull circumference at each age for each group and the numbers measured are shown in Fig. 6. The standards used are from the ICC London Growth Study.

At each group the means of the nonprivileged are less than even the female group of privileged children with $P<0.005, P<0.05$, and $P<0.02$ at ages 10,11 , and 12 , respectively. At each age the mean of the male skulls is $0.2-0.3 \mathrm{~cm}$ greater than the female, a difference similar to that of the 50 th centile of the standards. The privileged means lie around the 25 th centile and the nonprivileged just below the 10 th centile as was seen in the older infants in Fig. 1.

Skull circumferences were obtained in 8 Tamangs aged 10 to 12 years, who had a mean circumference of $51 \cdot 75$ $\mathrm{cm}$, and 6 Tibetans who had a mean of $51.8 \mathrm{~cm}$. These are larger than the nonprivileged NCBs (smaller than the privileged) but comparison between ethnic groups is confused by the different head shapes of the Aryan and the Tibeto-Burmese people.

\section{Diet}

Newars, Chettris, and Brahmins. The staple diet is rice which is eaten twice daily with dhal (a lentil soup) and a vegetable curry made predominantly with potato and a variety of coarse spinach. Many families are by choice vegetarian and, in addition, Chettris and Brahmins are forbidden by religion to eat eggs and some varieties of meat. For a poor nonvegetarian family the addition of meat or an egg to this meal is a weekly or monthly treat. Varieties of dried or curried high protein beans or grains, including groundnuts, maize, millet, and beans, are eaten as between meal snacks, as are curd, beaten rice, and fruit. Bread is more often made with rice than with wheat flour.

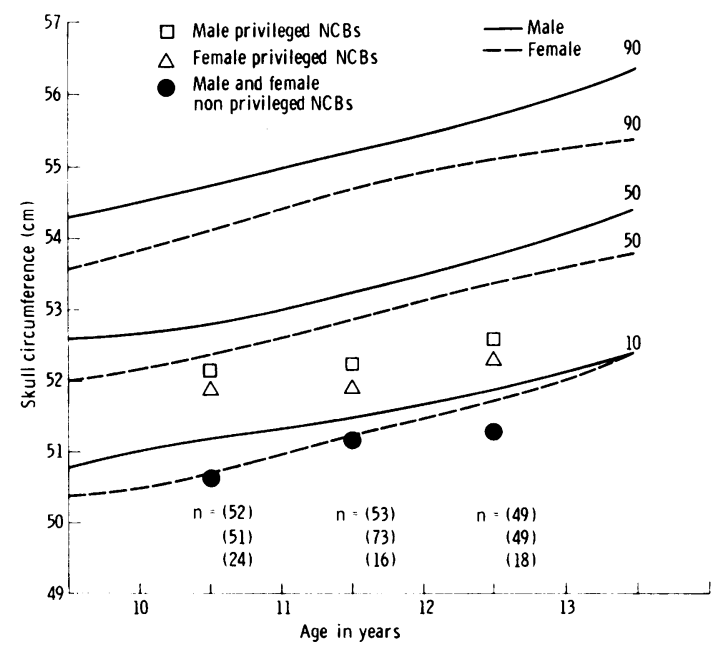

FIG. 6.-Mean measurements of skull circumference of privileged and nonprivileged NCBs of ages 10, 11, and 12 years.
The diet of the Brahmins and Chettris in the hill farm subgroup is similar except that the high protein vegetables are more abundant, bread is made from millet, and cow or buffalo milk is more often available.

The diet of the privileged family is similar except that the dhal is thicker, the curry contains more vegetables and, unless the family is vegetarian, eggs (only if Newar) or meat would be eaten most days.

Nonprivileged infant diet. Every baby is breast fed until after 2 years of age (sometimes 3 ) unless the mother becomes pregnant again. If maternal milk is insufficient complementary milk is given if available, powdered proprietary baby milk or dairy milk in Kathmandu, and cow or buffalo milk if a farm child. If no milk is available a paste of overcooked rice and water is used as a substitute-leeto. Unless leeto has had to be used early, milk alone is given until the 'rice feeding ceremony' which takes place at about 6 months. After this the child may be given rice and other solids, but often after the first ritualistic feeding of rice solid food continues to be withheld until it becomes obvious to the family, in the form of weight loss, that milk alone is insufficient. Weaning is complicated by the fact that the infant has already lost weight, and these older infants resist the introduction of solids. If complementary milk is being given feeding of solids is often further delayed. 8 infants between 6 months and 1 year were still not having solids. In the group between 1 and 2 years there were none on breast milk alone but 3 who were receiving complementary milk had still been given no solids.

Leeto is often used as a weaning food but in general there is little concept of preparing anything specially for an infant, and rice and dhal are started early. Vegetable curry is usually considered too hot for a small baby and withheld until after one year, but unfortunately this means that the infant has no green vegetables.

Even in the group between 1 and 2 years $20 \%$ were given neither green vegetables nor fruit. Meat and eggs if available are given to the older infants but in this same group only $50 \%$ had an egg or meat more often than once a month. The main source of protein is therefore the dhal, maize, groundnuts, wheat, millet, and beans. Except for dhal, these foods are eaten predominantly as between meal snacks, and in a form not easily digested by young infants, e.g. dried maize eaten by a malnourished infant with few teeth and chronic diarrhoea is destined to pass undigested in the stool. Rice is regarded as a holy food, whereas the high protein vegetables are often regarded merely as a poor substitute for rice, and as a result the poor urban family, without their own fields, sees no indication to spend their food budget on other than rice and dhal. The farm infants from around Gurkha were given more of these grains, but in total only $50 \%$ of the infants between 1 and 2 years received three or more of these sources of plant protein.

A further problem is the custom of eating only twice a day a predominantly rice meal, which has a high bulk per calorie ratio and is insufficient for a toddler. Another problem is the prevalence of diarrhoea and 
parasitic bowel infestations. Valuable foods are blamed for the illness and withheld. Dhal is thought to cause diarrhoea, and meat sepsis. Ascaris infestation is universal in the country but the heaviest infestations are in the toddler playing on the ground. In addition to the direct nutritional drain of the parasites themselves, the abdominal distension, pain, nausea, and anorexia they cause further interfere with nutrition.

Privileged infant diet. The diet of the privileged Newar, Chettri, or Brahmin infant is similar to that of the nonprivileged, with milk alone being given until after the rice feeding ceremony, the infant then being introduced to the adult diet of the family. Westernization has introduced bottle feeding, and 9 out of 15 infants under 6 months were receiving proprietary milks, though all but one was also being breast fed. The mothers believed they had insufficient milk and it appeared to be considered 'indelicate' to produce sufficient. Weaning, again often delayed if the infant appears to be thriving on milk alone, is onto the adult diet of the family, but 'Farex' has replaced leeto and is used extensively. The comparatively better diet of the family as a whole is shown in that all but one infant in the group between 1 and 2 years ate fruit or vegetables, and all but 3 had meat or eggs several times a week. The high protein grains and beans were regarded as second-rate food.

Tamangs. The Tamang diet is almost totally dependent on the produce of their own small farms. Therefore, along with a seasonal variation in diet, there is a variation depending on the altitude of the farm. The lower farms grow predominantly rice, whereas the higher ones more millet and maize. In general less rice is eaten by this group and more of the high protein grains and beans. There are no taboos regarding eggs or meat and no true vegetarians, but these foods are a rare treat.

Infant diet. This differs from that of the Newar/ Chettri/Brahmin group in that even if breast milk is abundant, it is the custom to start buffalo milk at 3 months. There is no rice feeding ceremony but solids are introduced at around 6 months, and deero, a paste made with a mixture of ground grains and water, replaces leeto.

Tibetan type people. The traditional staple of these people is tsampa, a paste the principal ingredients of which are barley flour, salt, yak butter, and water. The dietary habits of the groups studied, however, had been variously modified by contact with the outside. The Helambu Sherpas grow potatoes which were introduced as a second staple within the last 200 years, and more recently have imported rice, which is coming to be regarded as a prestige food. Potato curry and meat or eggs, as available, are eaten with the rice, but dhal is slow to cook at high altitude and is usually omitted. There are few food taboos and though many will not kill animals for religious reasons, they have no objection to eating animals which the Tamangs have killed for them.

The diet of the refugee Tibetans has had to be modified by the availability of their traditional foods at the lower altitude. Those who have remained in the Jwalikhel camp eat a diet similar to the valley Nepalis, whereas those who have left the camp eat tsampa, doughballs, and buffalo meat almost daily in addition to rice, dhal, and vegetables.

Infant diet. The Tibetan type infants are also breast fed until 2 years or over, and in the older infant complementary animal milks are given when available. Those in the camp received additional powdered baby milk from an aid project. Solids are traditionally started in the form of tsampa during the second week of.life, but the youngest in the survey being given solids was 3 months. The early solids are first chewed by the mother then spat into the infant's mouth. Mothers in the camp used tsampa less than the other groups, but in general throughout the whole group the custom is one of early introduction of solids and by 1 year a mixed diet including animal protein is being given to most infants. Excluding the Jwalikhel camp, $65 \%$ of the infants over 6 months ate eggs or meat more often than monthly, and $40 \%$ several times a week (cf. $50 \%$ of the NCBs over 1 year ate eggs or meat more often than monthly).

\section{Discussion}

Nonprivileged Newar/Chettri/Brahmin group. The mean measurements of this group lie approximately along the 10th centile until around 6 months of age and from then until 2 years lie progressively further below it. At 3 years the means lie somewhat nearer the 10th centile than they do at 2 years but thereafter remain approximately the same distance below it.

This is not the growth pattern of a genetically small race growing to its full genetic potential; rather it resembles the weight pattern found in malnourished children in both Africa and Asia and described by Jelliffe (1970). Weight gain in these children was found to be excellent in the first 6 months, poor in the second 6 months, and between 1 and 2 years often nonexistent or weight fell. Thereafter there was partial catch-up. The poor growth between 6 months and 2 years is thought in these studies to have been due to inadequate nutrition in the weaning period with the additional burden of heavy infestation of intestinal parasites.

The nonprivileged NCBs are known to have a diet at this age deficient in calories and protein. Vitamins A and B and iron are also low in the diet and deficiency states associated with them are all common. Hookworm infestation is often present and increases the iron deficiency anaemia, and heavy ascaris infestation is almost universal. 
In relating diet to arm circumference, which not only parallels that of other growth measurements but should be a more accurate measure of recent nutrition rather than of accumulated growth since birth, a close correlation is shown. (1) Satisfactory increase in muscle and fat while breast milk alone is sufficient-0 to 6 months. (2) No increase as breast milk alone becomes insufficient-6 to 9 months. (3) Loss of muscle and fat as breast milk alone becomes grossly inadequate-around 10 months. (4) Increase in muscle and fat as solids are started-10 to 14 months. (5) Little further increase during a period of inadequate diet, repeated gastroenteritis, and other infections, and a heavy ascaris infestation -1 to 2 years. (6) Futher increase after the critical weaning period.

The difference in the weight, height, and arm circumference measurements between the hill farm and valley subgroups of Chettris and Brahmins between 18 months and 2 years is probably a reflection of the more abundant milk and high protein vegetables in the hill farm child's diet. The failure to maintain the advantage in height after 3 years may be a measure of the greater poverty of the hill group.

Privileged Newar/Chettri/Brahmin group. The fall of the means through the centiles between 6 months and 2 years is less marked in the privileged group, but in Figs. 1 and 5 it can be seen that during the second year height falls from the 25th centile towards the 10th, and the weight to just below the 10th. By 4 years the height is again on the 25 th centile and remains there until 8 years. In Fig. 3 the arm circumference growth running parallel to, but better than, the nonprivileged NCBs correlates well with their similar but better diet. The greater arm circumference at birth appears to be an index of better maternal nutrition, and at 6 to 9 months to be related to the complementary milk delaying the adverse affects of late introduction of solids. In addition to the generally better diet, this group is also relatively free from parasitic infestations especially during early childhood.

Tamangs. No very young Tamang infants were measured, but after 3 months the growth pattern is similar to that of the nonprivileged NCBs except that (1) arm circumference and weight are greater between 3 and 6 months and are probably related to the custom of introducing animal milks at 3 months; (2) arm circumference and weight are greater between 1 and 2 years when the Tamang infant is receiving more milk and high protein vegetables; (3) the means do not return to the 10 th centile between 2 and 4 years, during which period the Tamang children were the smallest of the groups studied, despite their earlier advantage over the nonprivileged NCBs. This may due to the extreme poverty of the Tamangs and their general lack of food, but also by 3 years there is usually a younger sib who has priority for the buffalo milk.

Tibetan type. In the different areas studied the subgroups of these people differed markedly in wealth, dietary and other customs, and with regard to the altitude at which they lived. This diversity is reflected in the results from this comparatively small group; the deviations around the means are great and the means when plotted do not form smooth curves. Interpretation of the results is therefore difficult. The pattern differs from that of the nonprivileged NCBs on several points, for most of which there are possible dietary explanations. Mean birthweight and weight and arm circumference in the first 6 months are greater probably because maternal nutrition is better, and both tsampa and animal milks are introduced early. No mother with an infant under 3 months admitted to giving it tsampa, though they often agreed that many other mothers did. The early use of solids by the Tibetan type mothers is disapproved of by other Nepalis, and it is possible that tsampa (despite denials) was being used earlier than 3 months in the infants studied.

Infants being given tsampa would, in addition to being given extra calories, have an increased electrolyte load from the salt it usually contains. The custom of starting solids within the first 2 weeks and the resultant obesity in early infancy could be of benefit in the high plateau country of Tibet where hypothermia in small infants would seem a likely problem.

The growth falter in the Tibetan type group occurs later, at around 9 months and is not so severe as in the nonprivileged NCBs. The extra milk, tsampa, and generally better weaning customs partially explain this, but on diet history alone a falter at this age is not expected, and may be related more to infections and parasitic infestations. The height advantage over the nonprivileged NCBs at 2, 3 , and 4 years is to be expected from the diet before and during this period, but there is no obvious explanation for their inability to maintain the advantage during the school years.

A factor which may be of variable importance throughout the groups is iodine deficiency. Nepal is an area of endemic goitre and pockets of high incidence are mainly in hill areas where uniodized salt traded across the passes from Tibet is preferred 
to the iodized salt imported from India. Trisuli was the only area studied where goitres were common, and 5 of the older children from this area had small goitres.

Throughout the groups it can be seen that once a growth falter has occurred the subsequent return of the means towards the original centile is incomplete and the mean measurements in later childhood, though showing the expected increments between each age group, approach no nearer to the standards. This pattern is shown for height and arm circumference in Figs. 3 and 5 . The falter in skull circumference growth between 6 months and 2 years is shown in Fig. 1, and in Fig. 6 it can be seen that the privileged NCBs are still on the 25th and the nonprivileged on the 10th centiles, and the difference between the groups has remained static at around $1 \mathrm{~cm}$. Malnutrition in the first 2 years has been shown to be associated with impairment of mental development (Botha-Antoun, Babayan, and Harfouche, 1968; Swedish Nutritional Foundation, 1974). Assessments of mental development were not within the scope of the survey, but the falter in head circumference growth, occurring during a period of known malnutrition and at an age of critical brain growth, would seem to be important.

Growth patterns of the Nepali children are those of malnutrition in the second and third year causing physical and possibly mental stunting. Even the privileged group cannot be regarded as showing the true genetic growth potential of the race, as their growth also falters during this critical period, which corresponds with known deficiencies in their diet. Malnutrition is probably the underlying cause of many of the deaths in the second and third year, for though few die of malnutrition alone, many die of diseases such as measles and gastroenteritis. This malnutrition of the second and third year is largely avoidable in Nepal. It is not entirely due to poverty, and the weaning practices at fault are more the result of ignorance and custom than rigidly held beliefs.

This study was made possible through the generosity of the Wellcome Trust and the Gerber Division of C.P.C. (United Kingdom). I thank Dr. Bidro Pande and the staff of H.M.G. 'under 5's clinic', the United Mission to Nepal, the Helambu Family Planning Project, Dr. Y. P. Shrestha, and the staffs of St. Mary's, St. Xavier's, and Kanti Ishori Shishu Bidyala schools for allowing me to study their patients and pupils, and many other people in Nepal for their help; Drs. A. J. Keay and S. G. Ratcliffe for helpful discussion; and especially Dr. F. Cockburn for help in the handling of data.

\section{REFERENCES}

Botha-Antoun, E., Babayan, S., and Harfouche, J. K. (1968). Intellectual development related to nutritional status. Fournal of Tropical Paediatrics, 14, 112.

Gairdner, D., and Pearson, J. (1971). A growth chart for premature and other infants. Archives of Disease in Childhood, 46, 783.

Habicht, J. P. Martorell, R. Yarbrough, C., Malina, R. M., and Klein, R. E. (1974). Height and weight standards for preschool children. Lancet, $1,611$.

Gómez, F., Galvan, R. R., Frenk, S., Muñez, J. C., Chávez, R., and Vázquez, J. (1956). Mortality in second and third degree malnutrition. Fournal of Tropical Paediatrics, 2, 77.

Jelliffe, D. B. (1970). (Editor). Diseases of Children in the Subtropics and Tropics. Arnold, London.

Jelliffe, E. F. P., and Jelliffe, D. B. (1969). The arm circumference as a public health index of protein-calorie malnutrition of early childhood. Fournal of Tropical Paediatrics, 15, 179.

Swedish Nutritional Foundational Symposia No. XII (1974). Early Malnutrition and Mental Development. Ed. by J. Cravioto, L. Hambraeus, and B. Vahlquist. Almquist and Wiksell, Stockholm.

Tanner, J. M., Whitehouse, R. H., and Takaishi, M. (1966). Standards from birth to maturity for height, weight, height velocity, and weight velocity: British children, 1965. Archives of Disease in Childhood, 41, 454 and 613.

Waterlow, J. C. (1974). Some aspects of childhood malnutrition as a public health problem. Britsh Medical fournal, 4, 88.

Correspondence to Dr. S. Margaret Farquharson, 6 Chamberlain Road, Edinburgh 10. 